Boda Mihály ${ }^{1 \oplus}$

\title{
Egy magyar geopolitikai elmélet a két világháború között: a naturalizált szentkorona-eszme ${ }^{2}$
}

\section{A Hungarian Geopolitical Theory between the Two World Wars: The Naturalised Idea of the Holy Crown}

\section{Absztrakt}

A 19. században és a 20. század elsö felében több tudomány keretein belül is megfogalmaztak háborús vagy külpolitikai ideológiát. E tudományok közé tartozott a földrajz is, amely geopolitika címszó alatt járult hozzá a külpolitika formálásához. A korszak geopolitikai gondolkodásának komoly jelentősége volt a kiterjedt tengerparttal rendelkezö országokban, de a szárazföldi országokban, így Magyarországon is. A magyar geopolitikai gondolkodásnak két nagy típusa alakult ki. Az egyik fö gondolkodási irány a magyar állam valós vagy vágyott természeti határaira épített, a másik pedig a magyar államnak a szomszédos kultúrák között elfoglalt határhelyzeti pozíciójára. Az alábbi tanulmány a természeti határokra épitő elméletek egyik - a szentkorona-eszméhez is kapcsolódó - típusával foglalkozik.

Kulcsszavak: háborús ideológia, magyar geopolitika, szentkorona-eszme, Kárpátmedence, Teleki Pál, Fodor Ferenc, Kalmár Gusztáv

\section{Abstract}

In the $19^{\text {th }}$ century and the first half of the $20^{\text {th }}$ century warfare and foreign policy ideologies were suggested on many fields of science. Geography as geopolitics was certainly one of these fields. Geopolitical thinking had serious significance in the

Nemzeti Közszolgálati Egyetem Hadtudományi és Honvédtisztképző Kar Hadtörténelmi, Filozófiai és Kultúrtörténeti Tanszék, tanszékvezető egyetemi docens - University of Public Service, Faculty of Military Sciences and Officer Training, Department of Military History, Philosophy, and Cultural History, Head of Department, Associate Professor, e-mail: boda.mihaly@uni-nke.hu

2 A tanulmány az Innovációs és Technológiai Minisztérium ÚNKP-21-5-NKE-2 kódszámú Új Nemzeti Kiválósági Programjának a Nemzeti Kutatási, Fejlesztési és Innovációs Alapból finanszírozott szakmai támogatásával készült. 
political thought of countries having long shores, and terrene countries, like Hungary as well. Two main branches of geopolitical ideas occurred in Hungary at that time. One took natural phenomena as real or desired borders of Hungary as a basic issue, the other listened to the special position of Hungary between different cultures. This paper deals with one of the ideologies based on the natural borders of Hungary, the naturalised idea of the Holy Crown.

Keywords: warfare ideology, Hungarian geopolitics, idea of the Holy Crown, Carpathian Basin, Pál Teleki, Ferenc Fodor, Gusztáv Kalmár

\section{Bevezetés: a földrajztudomány fejlödése a 19. század második felében}

A 19. századi háborús ideológiák - a főként a vallásra támaszkodó korábbi ideológiákkal szemben - a században kialakuló tudományokra épültek. ${ }^{3}$ Az egyik ilyen tudomány a földrajz volt. A földrajz mint tudomány a Föld felszínére vonatkozó ismeretek tudományos rendszerét foglalja magában. Az ismeretek egy része a természeti jelenségekre vonatkozik, egy másik része pedig az ember által létrehozott mesterséges jelenségekre. A 19. század második felében a földrajztudománynak két, az emberi jelenségekkel foglalkozó ága alakult ki, a politikai földrajz és a geopolitika. ${ }^{4} \mathrm{~A}$ politikai földrajz leíró tudomány, a föld felszínének politikai szempontból való leírását adja, és ma is része a földrajztudománynak. A geopolitika ezzel szemben a természet emberre gyakorolt hatásának hangsúlyozásával ${ }^{5}$ jobban épít a politikai, előíró tartalomra, és (kül-) politikai előírásokat és magyarázatokat fogalmaz meg. ${ }^{6} \mathrm{~A}$ két tudományág hasonló előfeltevéseken nyugodott, azonban a geopolitika sokkal inkább megfelelt a 19. század nacionalista és imperialista törekvéseinek. ${ }^{7}$ Ez a két tudományág ezért, bár a 19. század második felének kritériumai szerint egyaránt a földrajztudomány részének számított, mai szemmel nézve nem egyenlően teljesítette a tudományosságnak a leíráson alapuló mércéjét, ${ }^{8}$ illetve nem ugyanannak a tudománynak a mércéjét teljesítette.

A geopolitikával ugyanis más a helyzet, mint a korszak többi - mai szemmel nézve - féltudományos elméletével. A történelmi historizmus vagy a biológiai szociáldarwinizmus a korszakban elfogadott tudományos megközelítésnek számítottak,

Boda Mihály: A háború tudományos igazolása a 19-20. század fordulóján Európában és Magyarországon: a filozófiai militarizmus. Hadtudomány, 31. 2021a (megjelenés előtt); Mihály Boda: Imperial Historicism: An Example of Scientific Justification of Foreign Policy and Warfare in the 19-20th Centuries in Hungary. AARMS, 20. 2021b (megjelenés elött).

4 A földrajztudomány és a magyar földrajztudomány általános fejlődéséről a korszakban lásd Gróf Teleki Pál: $A$ földrajzi gondolat története. Budapest, Szerzői kiadás, 1917. 52-147; Fodor Ferenc: A magyar földrajztudomány története. Budapest, Magyar Tudományos Akadémia Földrajztudományi Kutatóintézete, 2006. 119-285.

Teleki (1917): i. m. 52-54.

6 Szilágyi István: A geopolitika elmélete. Budapest, Pallas Athéné, 2018. 18; Ladis K. D. Kristof: The origins and evolution of geopolitics. Journal of Conflict Resolution, 4. (1960), 1. 34-36; Palotás Zoltán: A geopolitika mint államtudomány. Hitel, 8. (1943), 2. 101.

7 Tóth József (szerk.): Általános társadalomföldrajz I-II. Budapest, Dialóg Campus Kiadó - Nordex Kft., 2014. 8.2.2.1; Gyuris Ferenc: Variációk egy témára: Hunfalvy, Lóczy és Czirbusz földrajz-felfogásának nemzetközi kapcsolódásai. Földrajzi Közlemények, 144. (2020), 4. 397-398; Mark Bassin: Imperialism and the nation state in Friedrich Ratzel's political geography. Progress in Human Geography, 11. (1987), 4. 473-495.

8 Vö. Max Weber: A tudomány mint hivatás. In Max Weber: A tudomány és a politika mint hivatás. Budapest, Kossuth, 1995. 34. 
ugyanakkor a tudományfejlődés során a történelem és a biológia meghaladta ezeket az elméleteket, és ma nem is tekintik őket tudománynak. ${ }^{9}$ A geopolitika a historizmushoz és a szociáldarwinizmushoz hasonlóan szintén kiszakadt a földrajzból (és a természettudományokból), azonban ezt követően külön (társadalom)tudománnyá vált.10

A geopolitikának Európában a 19-20. század fordulóján több - egymást nem kizáró - típusa alakult ki. A német geopolitikai iskola egy szárazföldi hatalom kiszolgálójaként főként a szárazföld felöl szemlélte a Föld felszínét, Európával a fókuszában; az angolszáz geopolitikai iskola egy tengeri hatalom támogatójaként azonban inkább a tenger felől, amibe az Európán kívüli világ is belefért. Emellett, néhány geopolitikus inkább hosszú távon, történeti dimenzióban vizsgálta az állam földrajzi környezetét, mások azonban inkább a relatíve rövid távú stratégiai és biztonságpolitikai érdekeket tartották szem előtt. ${ }^{11}$

Magyarországon a geopolitikai gondolatok az Al-Duna szabályozásával, illetve a pánszlávizmussal való ideológiai szembenállással összefüggésben már a német Friedrich Ratzel (1844-1904) munkássága előtt teret nyertek, ${ }^{12}$ azonban a geopolitikai gondolkodás a német geopolitika hatására vált intenzívebbé. A német politikai földrajzi és geopolitikai elméletek már korán elértek Magyarországra, ${ }^{13}$ Ratzelnek a természeti határoknak a jelentőségét hangsúlyozó müvét ( $A$ Föld és az ember, 1882) 1887-ben le is fordították magyarra. ${ }^{14}$ Az eredeti művet Ratzel és a magyar fordító még ki is egészítették egy Magyarországra vonatkozó fejezettel. Ratzel hatása a két világháború között is éreztette hatását a magyar elméleteken. A ratzeli hatást kiegészítették a határhelyzeti ideológiák, azaz az I. világháború előtt a pánszlávizmussal és a pángermanizmussal, a két világháború között pedig a bolsevizmussal való szembeszállást támogató elméletek, illetve a kelet és a nyugat közötti közvetítést támogató elképzelések. A geopolitikának a Ratzel-féle történeti változata mellett így, a két világháború között, Harold J. Mackinder (1861-1947) és Karl Haushofer (1869-1946) hatására megjelent a stratégiai és biztonságpolitikai geopolitika is.

Alább a természeti határokra építő elméletek egyikével - a Kárpát-medencei határokra építő elmélettel - foglalkozom, és annak a megmutatására törekszem, hogy ez a geopolitikai elmélet tekinthető a szentkorona-eszme naturalizált - természeti jellegzetességekre való hivatkozással interpretált - változatának. Megközelítésem nehézségét az adja, hogy a témában író szerzők müveikben nem, vagy csak odavetett jelleggel hivatkoznak a Szent Koronára. Így Fodor Ferenc és Kalmár Gusztáv nem említik a "Szent Korona" kifejezést, Teleki Pál pedig csak hozzávetőlegesen említi. Ugyanakkor a korszak belpolitikai gondolkodásában a szentkorona-eszmének meghatározó szerepe volt, illetve a vizsgált geopolitikai elméletek tartalma is jelentős

Vö. Romsics Ignác: Clio büvöletében. Budapest, Osiris, 2011. 46-76.

Szilágyi (2018): i. m. 11.

Szilágyi (2018): i. m. 29-79; Kristof (1960): i. m. 37-38; Kjell Engelbrekt: A brief intellectual history of geopolitical thought and its relevance to the Baltic region. Global Affairs, 4. (2018), 4-5. 476-478.

12 Lásd Pulszky Ferenc: Töredékes észrevételek a Dunaszabályozás 's keleti kérdés iránt. Pozsony, Schmid Antal, 1840; Wesselényi Miklós: Szózat a' magyar és a szláv nemzetiség' ügyében. Lipcse, Wigand Ottó, 1843.

13 Hajdú Zoltán: Friedrich Ratzel hatása a magyar földrajztudományban. Tér és Társadalom, 12. (1998), 3. 96-99; Gyuris (2020): i. m. 396-410.

14 Ratzel Frigyes: A Föld és az ember. Anthropo-geográphia vagy a földrajz történeti alkalmazásának alapvonalai. Budapest, Magyar Tudományos Akadémia, 1887. 
átfedést mutat a 19. század második felére és a két világháború közötti időszakra is jellemző historizáló szentkorona-eszmével. Ezen érvek alapján úgy vélem, hogy a két világháború közötti magyar geopolitikai elméletek egy része nevezhető geopolitikai vagy naturalizált szentkorona-eszmének.

\section{A szentkorona-eszme a 19. század második felében és a két világháború között: a historizált szentkorona-eszme}

A szentkorona-eszmére a 19. század második felében főként Werbőczy István (14651541) szokásjogi gyüjteménye (Hármaskönyv) nyomán, jogi fogalomként hivatkoztak, amit azonban ekkor történeti tartalommal töltöttek meg, historizáltak. Az eszme keretein belül a történeti tartalomnak olyan közjogi és politikai következtetéseket kellett igazolnia, amelyek felhasználhatók voltak Magyarországnak a Habsburg uralkodóval, a nemzeti kisebbségekkel és a korábbi magyar területekkel szembeni viszonyában.

A historizált szentkorona-eszmére való hivatkozás a 19. század második felében legalább két elemet foglalt magában, amelyek külön-külön is kapcsolhatók az eszméhez. Ezek az elemek: a szentkorona-eszme történészi értelmezésében a magyar nép történelmi hivatása a környező népek integrálásában, azaz e népek békéjének, védelmének és civilizációjának biztosítása; illetve a szentkorona-eszme historizáló jogászi értelmezésében Magyarország politikai sajátosságaira alapozott részleges politikai függetlensége. Ez utóbbit szentkorona-tannak (és nem csupán eszmének) is nevezzük. A jelen tanulmány keretei között a két elem közül most csak a magyar nép történelmi hivatásának mibenlétére van szükség. ${ }^{15}$

A magyar nép más népeket összekapcsoló történelmi hivatását a 19. században főként a történészek tartották fontosnak. A század közepén és második felében Horváth Mihály (1809-1878) és Ipolyi Arnold (1823-1886) is a szabadságadás fontosságát hangsúlyozták. Horváth műveinek alapvetése, hogy az emberi történelem végcélja a polgári világ kialakulása, amikor is az egész emberiség szabadságban és egyenlőségben fog élni. ${ }^{16}$ A magyarok ebben a történelemben „lángoló szabadságszeretetükkel" tünnek ki (a nemesek számára, az alkotmány biztosította szabadságok szeretetével), ami többek között a környező népekhez való testvéries, fegyvertársi viszony kialakításában fejeződött ki. ${ }^{17}$ Ipolyi hasonlóan vélekedett:

„A magyarok meghódítván az országot, nem állítottak föl különbséget, mint más nemzetek tevék, a hódítók és hódított nép között. Nem követeltek az uralkodó nemzetiség számára sem hegemóniát, sem kiváltságot és külön jogokat. Nem emeltek válaszfalat a nemzetiségek közt, nem alkottak kasztokat. Nem voltak rasszátkozottaik, mint a franciáknak, nem elnyomottjaik, mint az angoloknak, vagy helótáik, mint Hellasz szabad s művelt népének, vagy rabszolganépeik, mint a szabad amerikai köztársaság négerei s a törvényen kívül álló indiánjai. [...] Mindenki, amint a magyar közjog szerint a magyar

Lásd Boda 2021b i. m.

Romsics (2011): i. m. 86.

Idézi Romsics (2011): i. m. 126 
korona tagjává lett, volt légyen bármilyen nyelvü és nemzetiségü, annak egyformán minden szabadságában részesült, s a nemzet uralkodó tagjává lőn."18

Az ország nem magyar ajkú népeinek a magyarokkal való összekapcsolódása számukra így nem alávetettséget hozott, hanem az alkotmány biztosította szabadságot. Ipolyi szerint ez a nem magyarok és magyarok közötti speciális viszony a saját korára nézve történeti jogokat és történeti kötelességeket eredményez az érintett népek számára. A magyar nemzetnek például a történelme alapján joga van a magyar államnyelvhez. Ám, ugyancsak a történelem alapján, a magasabb szellemi tehetségének köszönhetően kötelessége is befolyást gyakorolni a kevésbé fejlett népekre, mivel a közös ország közjavát csak így lehet biztosítani. ${ }^{19}$

Ipolyi a történelmet vizsgálva több olyan magyar társadalmi intézményre hívta fel a figyelmet, amelynek a segítségével a magyarok képesek voltak megvalósítani történelmi hivatásukat. Ilyen intézmények voltak a vérszerződés, a magyar apostoli királyság és Werbőczy szentkorona-eszméje. ${ }^{20}$

A két világháború közötti korszakban a szentkorona-eszme a korábbi időszakhoz hasonlóan fontos szerepet játszott. A korszakban az eszme egyik megjelenési formája a belpolitikai kérdésekben alkalmazott jogi érvelés volt, a másik pedig a Szent István-i, ezeréves Magyarországra való jogászi hivatkozás.

Az egyik belpolitikai problémát a politikai berendezkedés kérdése szolgáltatta. Az 1920-as években komoly vita dúlt a Habsburg Károly visszatérését támogató legitimisták, és az új királyt választani kívánó szabad királyválasztók között. A két párt abban ugyan egyetértett, hogy a szentkorona-eszmére kell támaszkodni, azonban az eszmét másként igyekeztek felhasználni. A legitimisták számára az volt a fontos, hogy az 1918-as és 1919-es forradalmak után a szentkorona-eszme biztosítja az alaki jogfolytonosságot, azaz hogy csak az a törvény lehet jogszerü, amit a király és az országgyülés együtt alkot (így a forradalmi törvények nem jogszerüek). A szabad királyválasztók ezzel szemben azt hangsúlyozták, hogy mivel a király lemondásával a királyi funkció gyakorlása megszünt, a Werbőczy Hármaskönyvében megjelenő szentkorona-eszme biztosítja az anyagi jogfolytonosságot, mert lehetővé teszi új király választását. ${ }^{21}$ Az 1920-as évek végétől számos törvény ismerte el a szentkorona-eszme közjogi funkcióját, hogy minden hatalom forrása a Szent Korona. Így hivatkoztak rá például a Szent Korona és a koronázási ékszerek őrzéséről szóló törvényben, vagy az állami bíróságokról szóló törvényben. ${ }^{22}$

A Szent István-i, ezeréves Magyarországra való hivatkozásban kiemelkedő szerepe volt Egyed Istvánnak (1886-1966) és Molnár Kálmánnak (1881-1961). Egyed úgy vélekedik, hogy:

18 Ipolyi Arnold: A magyar nemzetegység és államnyelv történeti alakulása. In Rómer Flóris - Ipolyi Arnold - Fraknói Vilmos: Egyház, müveltség, történetírás. Budapest, Gondolat, 1981. 102.

19 Ipolyi (1981): i. m. 108-113.

20 Ipolyi (1981): i. m. 102-103.

21 Egresi Katalin: A köztársasági eszme és a Szent Korona-tan a magyar politikai gondolkodásban a két világháború között. In Feitl István (szerk.): Köztársaság a modern kori történelem fényében. Budapest, Napvilág, 2007. 243-244. Bővebben: Kardos József: A szentkorona-tan története 1919-1944. Budapest, Akadémiai Kiadó, 1965.

22 Egresi (2007): i. m. 251-253. 
„[a] magyar állam nemzeti jellege nem akadályozta soha a nem magyar anyanyelvü polgártásainkkal való békés együttélést. Szent István király hagyta örökül fiához intézett Intelmeiben ezt a békés politikát [...]. Szent István országai békés otthont biztosítottak mindenkor a magyar állam minden anyanyelvü polgárának, azaz a szent korona minden népének". ${ }^{23}$

Molnár hasonlóan ír:

„[k]özjogi terminológiánk két gyűjtőfogalommal jelöli meg jogszemléletünknek néhány jellegzetes és állandó alapvonását. Ezek a szentistváni állameszme, s a szentkorona tana. A szentistváni állameszme a népfajok közötti megértésen és megbecsülésen nyugvó nemzetiségi politikánknak emberséges és mélymagyar jellegét domborítja ki. [...]

Nemzeti jogszemléletünk másik központja a szentkorona tana, amelyben a nemzet-szuverenitásnak évezredes nagy alaptétele jut hangos kifejezésre. A közösségi gondolat jegyében mereven visszautasítja a környező népek minket fojtogató patrimoniális eszmevilágát, - a másfajú és nyelvű polgártársainkkal pedig testvériesen osztja meg a szentkorona tagságával járó egyenlő jogokat és kötelességeket". ${ }^{24}$

Molnár itt először ugyan megkülönböztetni egymástól a Szent István-i állameszmét és a szentkorona-tant mint a népeket összekapcsoló politikát és a Magyarország szuverenitására támaszkodó politikát, azonban végül a népek összekapcsolását is beleveszi a szentkorona-tanba. Molnár egy másik helyen még egyértelmübben állítja, hogy: „Ma az állam: Csonkamagyarország. A szent korona: az ezeréves Magyarország". 25

Egyed és Molnár átvette a 19. század második felének historizáló szemléletmódját, és a szentkorona-eszme (illetve -tan) tartalmát a Szent Istváni-i, ezeréves Magyarország határinak visszaállításával azonosította. ${ }^{26}$

\section{A Kárpát-medence geopolitikája a két világháború között: a naturalizált szentkorona-eszme}

A két világháború közötti magyar geopolitikai elméletek egy részében szintén komoly hangsúlyt fektettek a szerzők a Szent István-i, ezeréves Magyarország gondolatára, illetve annak a Kárpát-medencével való azonosítására. A magyar geopolitika ezen formájának három képviselője Fodor Ferenc, Kalmár Gusztáv és Teleki Pál.

Egyed István: Különlenyomat a Pesti Hírlap Az ezeréves Magyarország címü kiadványából. Budapest, 1939. 251.

24 Molnár Kálmán: Alkotmányfejlődésünk útjai. In Kajtár István (szerk.): Alkotmányfejlődésünk útjai. Válogatás Molnár Kálmán hátrahagyott írásaiból. Pécs, PTE ÁJK, 2011. 114.

25 Molnár Kálmán: A Szent Korona-tan kifejlődése és mai jelentősége (A magyar nők Szent Korona Szövetségében 1927. február 2-án tartott előadás). Pécs, Dunántúl Egyetemi Nyomdája, 1927. 13.

26 Vö. Kardos (1965): i. m. 219-225. 


\subsection{Fodor Ferenc és a medenceállam harmonikus egysége}

A trianoni békeszerződés következményeit földrajzi szempontból ismertető Fodor Ferenc (1887-1962) A trianoni szerződés földrajzi megvilágításban címü írásában úgy véli, hogy az állam a politikailag-kulturálisan megszervezett népből és a politikailag-kulturálisan megszervezett földből áll. A békeszerződéseket illető alapvető kritikájának lényege, hogy az csak a népet (a népek önrendelkezési jogát) vette figyelembe, a földet és a nép földdel való kapcsolatát nem. Ez azért különösen problémás Európának ezen a részén, mert itt a népek keveredése miatt nem lehet éles néprajzi határokat húzni a népek között. Az itt élő népeknek, Magyarországot is ide véve, nem lehet politikai ideálja a nemzeti állam. ${ }^{27}$

Fodor szerint Magyarország a békeszerződés előtt medenceállam volt, amely a centrális területek mellett a peremterületeket is magában foglalta, és csak Ausztria és Szerbia felé volt nyitottabb (utóbbi felöl folyó határolta), a többi oldalról a legerősebb természeti határok, hegységek (a Kárpátok) vették körül. A békeszerződéssel az ország medencefenéki állam lett, centrális területekkel, de peremvidékek nélkül. ${ }^{28}$

A magyar medenceállam minden részével együtt adott ki egy harmonikus egészet, mert éghajlati, domborzati, vízrajzi és a növényvilág szempontjából is egységes egészet alkotott, amire a történelem során ráépült a gazdasági, kulturális és politikai egység. A magyar medenceállam a Szent István-i államalakulattal volt azonos, „DélkeletEurópa felé [...] az utolsó kultúrtáj a szó európai értelmében". ${ }^{29} \mathrm{Ez}$ az államalakulat olyan nemzetiségi (nem nemzeti) állam volt, amelyben az államalkotó nemzet számbeli többségben és kulturális fölényben volt a nemzetiségekkel szemben. Az államalkotó nemzet a peremvidéken elhelyezkedő nemzetiségek között, a centrális részeken élt, és politikailag, gazdaságilag és kulturálisan összetartotta az államot. ${ }^{30} \mathrm{~A}$ trianoni szerződés szétrombolta ezt a földrajzi egységen nyugvó politikai, gazdasági és kulturális egységet, és néprajzilag tarka, gazdaságilag pedig önállótlan nemzeti államokat hozott létre. ${ }^{31}$ Fodor végkövetkeztetése, hogy az állam csak akkor lehet erős, ha számol a földrajzi feltételekkel, és törekszik azok elérésére, azaz a revízióra. ${ }^{32}$

\subsection{Kalmár Gusztáv és a Kárpát-medence gazdasági egysége}

Fodor munkájában találunk arra hivatkozást, hogy a földrajzi jellegzetességek által meghatározott Kárpát-medencei magyar állam azonos a Szent István-i történelmi magyar állammal. Kalmár Gusztáv (1892-1949) Fodorhoz hasonlóan a Szent István-i birodalom és a Kárpát-medence azonosságát hangsúlyozza:

27 Fodor Ferenc: A trianoni szerződés földrajzi megvilágításban. In Igazságot Magyarországnak. A trianoni békeszerződés következményeinek ismertetése és birálata. Budapest, Magyar Külügyi Társaság, 1928. 350-351; 377-378.

28 Fodor (1928): i. m. 352-356; 373.

29 Fodor (1928): i. m. 371.

30 Fodor (1928): i. m. 379.

31 Lásd Málnási Ödön: Csonka-Magyarország katonai földrajzi helyzete. Földrajzi Közlemények, 53. (1925), 4-5. 49-66.

32 Fodor (1928): i. m. 382. 


\begin{abstract}
„A természeti egység parancsoló szava olyan erős, hogy hosszabb-rövidebb idő multán a Kárpáti-medence politikai egysége mindig helyreállt. Más szóval úgy is mondhatjuk, hogy Magyarország történeti egységének a magyarság hazaszeretete mellett legjelentősebb tényezője az ország természeti egysége. [...] Kárpáti-medencén Szent István birodalmát, a világháború előtti Magyarországot értjük." ${ }^{33}$
\end{abstract}

A Szent István-i államot Kalmár a Kárpát-medencéhez kapcsolja, és attól megkülönbözteti a nagyobb Közép-Duna-medencén alapuló lehetséges államot. Utóbbi határait azok a hegységek alkotják, ahonnan a Duna és a Száva mellékfolyói erednek. A Kárpát-medence déli határa ezzel szemben nem lépi át a Szávát és az Al-Dunát. ${ }^{34}$

Kalmár, Fodorhoz hasonlóan az államot a terület és nép egységeként határozza meg. ${ }^{35}$ Ennek az egységnek az alapját a Kárpát-medence természeti-földrajzi egysége adja, arra épül rá a gazdasági, politikai és történeti egység. ${ }^{36}$ A földrajzi egyéget képező állam két fontos tulajdonsága, hogy gazdaságilag elegendő a lakosság számára, illetve hogy olyan határokkal rendelkezik, amelyeken túl nem terjeszkedhet az állam, ám amiből elvenni sem lehet. Mind a túlterjeszkedés, mind az elvétel a „természet elleni bün". ${ }^{37}$ Ennek az elvnek a történeti leképeződése, hogy a koronázási esküvel minden királynak meg kellett fogadnia, hogy az országhatárok épségén őrködik, illetve hogy az elszakított részeket visszaszerzi. ${ }^{38} \mathrm{~A}$ Kárpát-medence egysége stabil határokat eredményezett Magyarország számára, ami azonban a trianoni békével megszűnt. A legfőbb geopolitikai követelmény viszont minden állam és Magyarország számára az ország területi és népi egységének biztosítása, azaz a revízió. ${ }^{39}$

\title{
3.3. Teleki Pál és az Európa szerves fejlődésére alapozott európai öntudat
}

Fodorral és Kalmárral szemben Teleki Pálnak (1879-1941) a két világháború közötti írásaiban találunk hivatkozást a „Szent István Koronájának Országá"-ra és „a szent korona birodalmához való tartozás"-ra. ${ }^{40}$ Teleki továbbá, szintén Fodorral és Kalmárral ellentétben, nemcsak Magyarország szűk földrajzi környezetéről ír, hanem az egész világgazdaságot, világpolitikát, és abban Európa helyzetét veszi figyelembe. A legfontosabb ide kapcsolódó írásai az Időszerü nemzetközi kérdések a politikai földrajz megvilágításában és az Európa problémája címü tanulmányok.

Teleki saját bevallása szerint politikai földrajzot müvel és nem geopolitikát (ahogyan Ratzelt is a politikai földrajz müvelői közé sorolja). A politikai földrajz a földfelszín folyamataival foglalkozik, így a szerves (organikus) és az emberi szervezésen alapuló (organizatorikus) folyamatokkal. Utóbbi kategóriába tartoznak a politikai és gazdasági

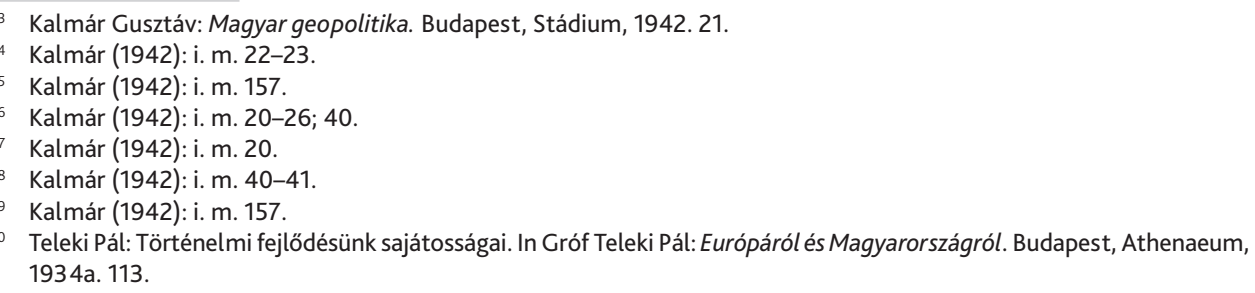


folyamatok. A szervezésen alapuló folyamatok csak egy idő után jelennek meg a földfelszínen, a szerves folyamatok azonban mindig is ott voltak, és a szervezésen alapuló folyamatok megjelenése után is ott lesznek. A szervezésen alapuló folyamatok ideig-óráig eltéríthették a szerves folyamatokat, azonban a szerves folyamatok végül mindig diadalmaskodtak a történelemben. ${ }^{41}$

A földfelszínt kamarák és nagytájak tagolják. A földfelszín a klíma szerint kamarákra van tagolva, amelyeken belül a gazdálkodás módja, az életrend és a politikai gondolkodás egységes, és különbözik más kamarákétól. A kamarák államai kénytelenek együtt élni és együtt fejlődni. Ilyen kamara például Európa Oroszország nélkül, de a Földközi-tengerrel együtt, és Észak-Amerika. A kamarákon belül nagytájak találhatók, amelyeken - ahol a történelmi fejlődés megengedte - nemzetek alakultak ki. Európában ilyen nagytájak a Brit-szigetek, az Ibériai- és az Appennini-félsziget, a Párizsi-medence és a KözépDuna-medence (Telekinél ez a Kárpát-medencét jelenti), amelyek hozzávetőlegesen egymásához hasonló méretüek. A Közép-Duna-medencével szemben az egész Dunamedencét nem tartja nagytájnak, ${ }^{42}$ és így az arra ráépülő Osztrák-Magyar Monarchia létét is inkább a szervezésen alapuló jelenségek és nem a szerves jelenségek közé sorolja. Magyarország esetében a magyar nemzet Közép-Duna-medencében való létrejöttének folyamatát a trianoni békéhez is vezető török hódoltság derékba törte. ${ }^{43}$

A modern Európa szerves fejlődése a Római Birodalom bukása után kezdődött el. Az európai nagytájak lehetővé és maradandóvá tették a római provinciák tovább élését, a provinciák területén müködő egyház hatalmát, és a népvándorlás népeiből a nemzetek kialakulását. Az így kialakuló Európa sokszínű és tarka világ lett. ${ }^{44}$

Európa történelme a 20. század elejéig egybeesett a világtörténelemmel, azaz ami a történelemben a világ többi részén történt, az mindig az európai gyarmatosításhoz kapcsolódott. Az ipari forradalommal azonban a találmányok átalakították a világgazdaságot és a korábbi gyarmatok önállósultak, az I. világháborúval pedig Európa végleg elvesztette globális hegemóniáját. Az Európán kívüli kamarák és nagytájak (például Észak-Amerika, Dél-Amerika, Ausztrália) egyéniségük öntudatára ébredtek, ami tovább erősítette sajátos jellemvonásaikat. Teleki szerint a világ fejlődésének ebben a stádiumában kell kialakítani az erős európai öntudatot is. ${ }^{45}$

Az európai öntudatot az európai államok viszonyára kell alapozni. Az európai államok viszonya a területükön élő népekhez és egymáshoz azonban különbözik minden más kamara részeinek egymáshoz való viszonyától (például az Egyesült Államok [USA] államainak a viszonyától), illetve a kamarák és a világ különböző államainak az egymáshoz való viszonyától (a Népszövetség tagjainak a viszonyától). Az európai államok ugyanis nagy tájegységekhez kapcsolódnak (szemben az USA tagállamaival), és hosszú történelmük során szervesen fejlődtek ki, és nem csupán a szervezésen alapulnak (szemben a Népszövetséggel). Európa népei a történelem során kialakult

\footnotetext{
41 Teleki Pál: Időszerü nemzetközi kérdések a politikai földrajz megvilágításában. In Gróf Teleki Pál: Európáról és Magyarországról. Budapest, Athenaeum, 1934b. 76.

42 Teleki Pál: A »Donauraum« problémája. In Gróf Teleki Pál: Európáról és Magyarországról. Budapest, Athenaeum, 1934c. 153-154.

43 Teleki (1934b): i. m. 77-79.

44 Teleki Pál: Európa problémája. In Gróf Teleki Pál: Európáról és Magyarországról. Budapest, Athenaeum, 1934d. 96.

45 Teleki (1934d): i. m. 99-101.
} 
érzelmi kapcsolatban állnak földjükkel, ahogyan az ezeken a földeken történelmi korszakokon keresztül életegységben élő különböző népek is egymással. ${ }^{46}$

Az európai népek problémáit ezért nem lehet olyan, csupán kompromisszumos szerződésekkel rendezni, mint amilyen az l. világháborút lezáró békék. „Európa természetes életösztönével fog ráeszmélni, hogy a sokat hangoztatott »háborús felelősséggel« szemben egy sokkal súlyosabb felelősség, a »békék felelőssége « áll". ${ }^{47}$ Teleki szerint a „békék felelősségének" érdekében revízió alá kell venni a békeszerződéseket. A revízió Európa rekonstrukcióját jelenti, ami nem csupán a legyőzöttek érdeke, hanem egész Európáé, hogy visszaálljon a szerves fejlődés a csupán kompromisszumokon nyugvó, szervezésen alapuló fejlődéssel szemben, és ezzel megalapozza az európai öntudatot. ${ }^{48}$

A revízió pontos mibenlétéröl Telekinek nincsenek világos elképzelései, csak javaslatai. A revízióhoz szükségesnek tartja egy összeurópai politikai entitás létrehozását, amelynek joga van az állami szuverenitás sérelme nélkül intézkedni. Úgy véli továbbá, hogy ugyan a háború előtti állapotot nem lehet visszaállítani, ugyanakkor fontosnak tartja, a kényszerkisebbségek (nem önként vállalt és nem is a történelmi együttélésen alapuló kisebbségi státussal rendelkező népek) jogainak védelmét, illetve az ország gazdasági nehézségeinek (amelyek a területek elcsatolásából és a gazdasági önállóság elvesztéséből fakadnak) a megoldását. ${ }^{49} \mathrm{~A}$ „magyar állam feladata érlelni segíteni Európa lelkiismeretét a kisebbségi kérdéssel szemben". ${ }^{50}$

Teleki ugyan nem fejt ki szilárd véleményt, hogy miként kellene megoldani a magyar kisebbségek problémáját. Ugyanakkor, ha számba vesszük, hogy fontosnak tartja a KözépDuna-medencére épülö állam népeket tömörítő szerepét, akkor azt mondhatjuk, hogy egy önálló birodalomnak, a „szent korona birodalmának” a feltámasztására törekedett. ${ }^{51}$

\section{Konklúzió: a historizált szentkorona-eszmétől a naturalizált szentkorona-eszméig}

A két világháború között, ahogyan korábban és később is, a magyarországi háborús és külpolitikai ideológiák egy része Nyugat- vagy Kelet-Európából származó átvétel. Más magyarországi ideológiák ezzel szemben magyar eredettel rendelkeznek. Az egyik ilyen a szentkorona-eszme.

A szentkorona-eszme első megjelenési formája a középkori Küküllei János (13201339) nevéhez köthetö, amikor az eszme a bel-, és külpolitikai hatalomgyakorlás eszköze volt. ${ }^{52} \mathrm{Az}$ eszme a funkciójának megtalálása után Werbőczynél a jogi érv formáját vette fel, ${ }^{53}$ ami tovább élt a 19-20. században is. A jogi konklúzióval rendelkező

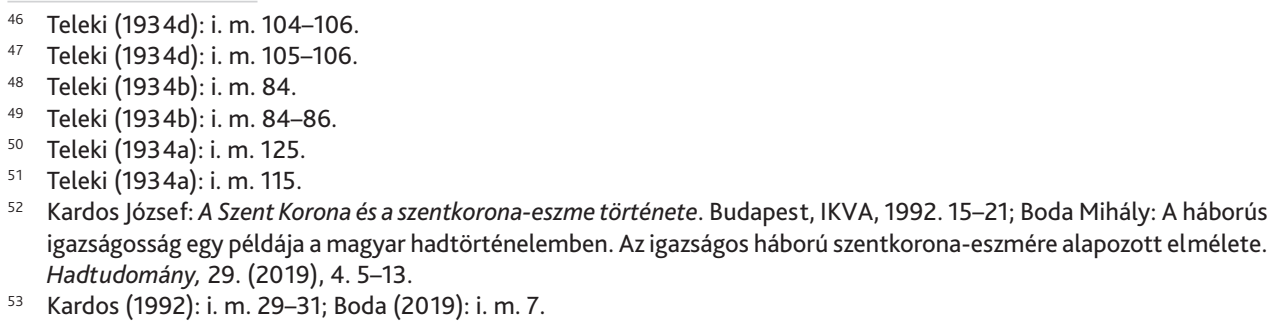
igazságosság egy példája a magyar hadtörténelemben. Az igazságos háború szentkorona-eszmére alapozott elmélete. Hadtudomány, 29. (2019), 4. 5-13.

$53 \operatorname{Kardos}$ (1992): i. m. 29-31; Boda (2019): i. m. 7. 
érvelés azonban a 19. században historikus történeti, majd a 20. század első felében geopolitikai tartalommal töltődött fel.

A tanulmányban annak a megmutatására törekedtem, hogy annak ellenére, hogy a „Szent Korona" kifejezés Telekit kivéve nem fordul elő a két világháború közötti magyar geopolitikai irodalomban, Fodor, Kalmár és Teleki geopolitikai elméletei tekinthetők a szentkorona-eszme naturalizált, geopolitikai formáinak. Az ismertetett elméletek tartalma ugyanis magában foglalja a 19-20. századra jellemző szentkorona-eszme alapvető részét, hogy a Szent István-i, ezeréves Magyarország határainak és szuverenitásának politikaformáló jelentősége van. Az eszmének az Osztrák-Magyar Monarchiában Magyarország belső politikai helyzetére és a korábbi magyar területek visszacsatolására irányuló politikai gondolkodásban volt jelentősége, a 20. században pedig a trianoni békeszerződés által elcsatolt területek (és népek) visszaszerzését támogató elméletalkotásban. Az eszme felhasználásának változása mellett az eredeti Szent István-i és ezeréves államiság gondolata kiegészült még egy geopolitikai elképzeléssel, hogy a Szent István-i és ezeréves magyar állam a Kárpát-medencével azonos. Így, amennyiben a Szent Korona a Szent István-i és ezeréves Magyarországot jelképezi, akkor azzal együtt a Kárpát-medencét is jelképezi, és a szentkorona-eszme értelmében nemcsak a Szent István-i és ezeréves határok visszaállítása szükséges, hanem a Kárpát-medence jelentette határok visszaállítása is. A historizált szentkorona-eszme helyett ezzel megszületett a naturalizált szentkorona-eszme.

\section{Felhasznált irodalom}

B. Wesselényi Miklós: Szózat a' magyar és a szláv nemzetiség' ügyében. Lipcse, Wigand Ottó, 1843.

Bassin, Mark: Imperialism and the nation state in Friedrich Ratzel's political geography. Progress in Human Geography, 11. (1987), 4. 473-495. Online: https:// doi.org/10.1177/030913258701100401

Boda Mihály: A háborús igazságosság egy példája a magyar hadtörténelemben. Az igazságos háború szentkorona-eszmére alapozott elmélete. Hadtudomány, 29. (2019), 4. 3-15.

Boda Mihály: A háború tudományos igazolása a 19-20. század fordulóján Európában és Magyarországon. A filozófiai militarizmus. Hadtudomány (megjelenés előtt). Boda Mihaly: Imperial Historicism: An Example of Scientific Justification of Foreign Policy and Warfare in the 19-20th Centuries in Hungary. AARMS (megjelenés elött). Egresi Katalin: A köztársasági eszme és a Szent Korona-tan a magyar politikai gondolkodásban a két világháború között. In Feitl István (szerk.): Köztársaság a modern kori történelem fényében. Budapest, Napvilág, 2007. 240-272.

Egyed István: Különlenyomat a Pesti Hírlap Az ezeréves Magyarország címü kiadványából. Budapest, 1939. 242-254.

Engelbrekt, Kjell: A brief intellectual history of geopolitical thought and its relevance to the Baltic region. Global Affairs, 4. (2018), 4-5. 475-485. Online: https://doi. org/10.1080/23340460.2018.1535256 
Fodor Ferenc: A trianoni szerződés földrajzi megvilágításban. In Igazságot Magyarországnak. A trianoni békeszerződés következményeinek ismertetése és birálata. Budapest, Magyar Külügyi Társaság, 1928. 347-386.

Gyuris Ferenc: Variációk egy témára: Hunfalvy, Lóczy és Czirbusz földrajz-felfogásának nemzetközi kapcsolódásai. Földrajzi Közlemények, 144. (2020), 4. 396-410. Online: https://doi.org/10.32643/fk.144.4.4

Hajdú Zoltán: Friedrich Ratzel hatása a magyar földrajztudományban. Tér és Társadalom, 12. (1998), 3. 93-104. Online: https://doi.org/10.17649/TET.12.3.475

Ipolyi Arnold: A magyar nemzetegység és államnyelv történeti alakulása. In Rómer Flóris -Ipolyi Arnold - Fraknói Vilmos: Egyház, müveltség, történetírás. Budapest, Gondolat, 1981. 97-119.

Kalmár Gusztáv: Magyar geopolitika. Budapest, Stádium, 1942.

Kardos József: A szentkorona-tan története 1919-1944. Budapest, Akadémiai Kiadó, 1985. Kardos József: A Szent Korona és a szentkorona-eszme története. Budapest, IKVA, 1992. Kristof, Ladis K. D.: The origins and evolution of geopolitics. Journal of Conflict Resolution, 4. (1960), 1. 15-51. Online: https://doi.org/10.1177/002200276000400103

Málnási Ödön: Csonka-Magyarország katonai földrajzi helyzete. Földrajzi Közlemények, 53. (1925), 4-5. 49-66.

Molnár Kálmán: Alkotmányfejlődésünk útjai. In Kajtár István (szerk.): Alkotmányfejlődésünk útjai. Válogatás Molnár Kálmán hátrahagyott írásaiból. Pécs, 2011. 103-120.

Molnár Kálmán: A Szent Korona-tan kifejlődése és mai jelentősége (A magyar nők Szent Korona Szövetségében 1927. február 2.-án tartott előadás). Pécs, PTE ÁJK, Dunántúl Egyetemi Nyomdája, 1927.

Palotás Zoltán: A geopolitika mint államtudomány. Hitel, 8. (1943), 2. 106-117.

Pulszky Ferenc: Töredékes észrevételek a Dunaszabályozás 's keleti kérdés iránt. Pozsony, Schmid Antal, 1840.

Ratzel Frigyes: A Föld és az ember. Anthropo-geográphia vagy a földrajz történeti alkalmazásának alapvonalai. Budapest, Magyar Tudományos Akadémia, 1887.

Romsics Ignác: Clio büvöletében. Budapest, Osiris, 2011.

Szilágyi István: A geopolitika elmélete. Budapest, Pallas Athéné, 2018.

Teleki Pál: A földrajzi gondolat története. Budapest, Szerzői kiadás, 1917.

Teleki Pál: Történelmi fejlődésünk sajátosságai. In Gróf Teleki Pál: Európáról és Magyarországról. Budapest, Athenaeum, 1934a. 109-125.

Teleki Pál: Időszerủ nemzetközi kérdések a politikai földrajz megvilágításában. In Gróf Teleki Pál: Európáról és Magyarországról. Budapest, Athenaeum, 1934b. 72-94.

Teleki Pál: A „Donauraum” problémája. In Gróf Teleki Pál: Európáról és Magyarországról. Budapest, Athenaeum, 1934c. 153-166.

Teleki Pál: Európa problémája. In Gróf Teleki Pál: Európáról és Magyarországról. Budapest, Athenaeum, 1934d. 95-108.

Tóth József (szerk.): Általános társadalomföldrajz I-II. Budapest, Dialóg Campus Nordex Kft., 2014.

Weber, Max: A tudomány mint hivatás. In Max Weber: A tudomány és a politika mint hivatás. Budapest, Kossuth, 1995. 5-51. 